The Agriculturists 12(2): 48-55 (2014) ISSN 2304-7321 (Online), ISSN 1729-5211 (Print)

\title{
Carbon and Nitrogen Dynamics and Carbon Sequestration in Soils under Different Residue Management
}

\author{
M. Mizanur Rahman \\ Department of Soil Science, Bangabandhu Sheikh Mujibur Rahman Agricultural University \\ Gazipur 1706, Bangladesh \\ *Corresponding author and Email: mizan@bsmrau.edu.bd
}

Received: 14 August 2014

Accepted: 13 December 2014

\begin{abstract}
A study was conducted at the research farm of Bangabandhu Sheikh Mujibur Rahman Agricultural University, Gazipur, Bangladesh during August 2011 to May 2012 in two consecutive rice seasons of T. aman and Boro using three types of organic residues viz. poultry manure, cowdung and rice straw as treatments to quantify their effects on soil carbon, nitrogen, carbon sequestration and $\mathrm{CO}_{2}$ emission. Poultry manure was found efficient to increase carbon and nitrogen contents in soils compared to rice straw and cowdung, which decreased with increased soil depths irrespective of residues. Rice straw released more $\mathrm{CO}_{2}$ compared to poultry manure and cowdung. However, a positive trend of carbon enrichment in soils was found with the application these residues. The carbon sequestration in soils under poultry manure was $1.46 \mathrm{t} \mathrm{ha}^{-1}$, while it was 1.26 and $1.19 \mathrm{t} \mathrm{ha}^{-1}$ in cowdung and rice straw, respectively. Application of poultry manure and cowdung in soils should be considered and recommended to increase carbon stock and fetch multiple benefits in agriculture.
\end{abstract}

Keywords: Carbon sequestration, nitrogen dynamics, poultry manure, cowdung, rice straw, $\mathrm{CO}_{2}$ emission

\section{Introduction}

Intensive cultivation of high yielding crop varieties using inorganic fertilizers solely and almost no recycling of organic residues have reduced soil organic carbon as well as other plant nutrients especially nitrogen, which leads to severe land degradation in Bangladesh (Karim et al., 1990; Rahman, 2010). Organic matter and nutrient deficiency also appeared as a great concern in the intensively cultivated areas due to lack of proper soil management by incorporating organic manures (Karim et al., 1990). Because of hyperthermic temperature regime, the rate of organic matter mineralization in soils of Bangladesh is usually very high, which is a basic problem in soil of Bangladesh (Karim and Iqbal, 2001). The present carbon status in soil is alarming and, therefore, proper and deliberate management of soil organic carbon is essential for the sustainability of agricultural production systems.

Soil organic matter is known as revolving nutrient fund that supplies mainly carbon, nitrogen, phosphorus and sulfur. Therefore, decline in soil carbon generally decreases crop productivity. Degradation of crop residues and organic wastes play a major role in global carbon and nitrogen cycling (Manzoni et al., 2008). Quantity and quality of carbon inputs, cropping intensity, soil and crop management practices 
affect carbon and nitrogen dynamics and carbon sequestration in different soil depths (Marland et al., 2004; Rahman, 2013).

The soil carbon is capable of enhancing agricultural sustainability and serving as a potential sink of atmospheric $\mathrm{CO}_{2}$. Carbon dioxide abundance in the atmosphere along with other greenhouse gases caused global warming and climate change. Sequestration of carbon in soils may potentially mitigate the negative effect of global warming on agriculture. Intensified rice based cropping systems consume more inputs and thereby release more $\mathrm{CO}_{2}$ and sequester less carbon in soil (Bhatia et al., 2011). Soil and cop management practices and organic materials that increase the stocks of soil carbon may have profound effects on climate mitigation (Soderstorm et al., 2014). Among different organic materials, poultry manure, cowdung and rice straw are used for crop production in Bangladesh. Rice based cropping system is dominant in Bangladesh and scarce information on carbon and nitrogen dynamics in different soil depths opened the avenues to conduct research in quantifying the effects of poultry manure, cowdung and rice straw in rice field on the availability of soil carbon and nitrogen and $\mathrm{CO}_{2}$ emission and carbon sequestration in soil.

\section{Materials and Methods}

\subsection{Experimental site and season}

The study was conducted at the research farm of Bangabandhu Sheikh Mujibur Rahman Agricultural University, Bangladesh located at $24.09^{\circ} \mathrm{N}$ latitude and $90.25^{\circ} \mathrm{E}$ longitudes with an elevation of $8.2 \mathrm{~m}$ from sea level, which is under the agro-ecological zone (AEZ) Madhupur Tract (AEZ 28). The experiment was conducted during August 2011 to May 2012 in two consecutive rice seasons of $\mathrm{T}$. aman (BRRI dhan49) and Boro (BRRI dhan29). The soil of the study site belongs to Salna series and has been classified as Inceptisol. The climate of the area is sub-tropical, wet and humid. Heavy rainfall occurs during June-July (269 to $370 \mathrm{~mm}$ ) and scanty rain during November to February (0 to $55 \mathrm{~mm}$ ).

\subsection{Physical and chemical properties of soils in the study plots}

Before starting the experiment, soil samples were collected from $0-5$ and 5-10, 10-15, 15-20 and $20-30 \mathrm{~cm}$ depths of the crop field for determining soil bulk density and $\mathrm{C}$ using standard methods (Page et al., 1982). The soil samples were air dried, ground to pass through 2 $\mathrm{mm}$ sieve and used for analysis (Table 1).

\subsection{Treatments and experimental design}

Three management practices viz. i) poultry manure (PM); ii) cowdung (CD); and iii) rice straw (RS) as treatments were laid out in a randomized complete block design with four replication. Considering the application rate $2 \mathrm{t} \mathrm{C}$ $\mathrm{ha}^{-1} \mathrm{PM}, \mathrm{CD}$ and RS were applied at 9.90, 10.81

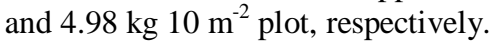

\subsection{Soil and crop management}

Thirty days old composted poultry manure and cowdung and dried rice straw cut into small pieces $(2-3 \mathrm{~cm})$ were broadcasted to rice fields during final land preparation in both $\mathrm{T}$. aman and Boro seasons. Poultry manure, CD and RS and plot soils were analyzed (Table 1) in the laboratory for N, P and K. Supplies of N, P and $\mathrm{K}$ from added $\mathrm{PM}, \mathrm{CD}$ and $\mathrm{RS}$ were determined and then doses of chemical fertilizers were calculated taking IPNS concept using BARC Fertilizer Recommendation Guide (BARC, 2005)

Thirty days old seedlings in T. aman and 40 days old seedlings in Boro were transplanted. The full doses of $\mathrm{P}$ and $\mathrm{K}$ were applied using triple super phosphate (TSP) and muriate of potash (MoP), respectively at the time of final land preparation. Nitrogen as urea was applied in three equal splits: 10 days after transplanting, at maximum tillering stage and at booting stage of the crop. Sulfur, zinc and Boron were not applied as these elements were present at high level in the experimental soils. 
Table 1. Organic carbon, total nitrogen, phosphorus and potassium in residues and manure used in the experiment (mean \pm S.D.)

\begin{tabular}{|c|c|c|c|c|}
\hline Residues & $\begin{array}{c}\text { Organic C } \\
(\%)\end{array}$ & Total $\mathrm{N}$ & Phosphorus & Potassium \\
\hline Poultry manure & $20.21 \pm 0.42$ & $2.09 \pm 0.15$ & $0.6 \pm 0.04$ & $0.84 \pm 0.12$ \\
\hline Cowdung & $18.50 \pm 0.21$ & $1.22 \pm 0.10$ & $1.01 \pm 0.15$ & $1.63 \pm 0.31$ \\
\hline Rice straw & $40.17 \pm 0.15$ & $0.44 \pm 0.08$ & $0.12 \pm 0.02$ & $1.65 \pm 0.33$ \\
\hline Plot soil & $1.12 \pm 0.17$ & $0.102 \pm 0.01$ & $5.7 \pm 1.00^{*}$ & $0.15 \pm 0.03 *$ \\
\hline
\end{tabular}

*Units of $\mathrm{P}$ and $\mathrm{K}$ in plot soils are $\mathrm{mg} \mathrm{kg}^{-1}$ and c-mol (+) $\mathrm{kg}^{-1}$, respectively .

Two seedlings were transplanted per hill. About $5-10 \mathrm{~cm}$ standing water was maintained in all plots. Soil samples were collected considering five depths viz. 0-5, 5-10, 10-15, 15-20 and 20$30 \mathrm{~cm}$ from each plot after Boro season (one year cycle of $\mathrm{T}$. aman and Boro) and were analyzed for soil bulk density, organic carbon, total nitrogen, ammonium and nitrate nitrogen using standard methods (Page et al., 1982).

\subsection{Carbon stock, carbon sequestration and carbon dioxide emission measurement}

Carbon stock and carbon sequestration were estimated using equation 1 and 2, respectively as follows:

$\mathrm{C}$ stock $\left(\mathrm{t} \mathrm{ha}^{-1}\right)=\mathrm{Conc}$. of soil $\mathrm{C}(\%) \mathrm{x}$ soil bulk density (g. c.c. $\left.{ }^{-1}\right)$ x soil depth (cm) .... (1)

$\mathrm{C}$ sequestration $=$ Final soil $\mathrm{C}-$ Initial soil $\mathrm{C}$ . (2) (Benbi and Senapati, 2010)

Carbon dioxide emission from rice field was measured through $\mathrm{NaOH}$ absorption following $\mathrm{HCl}$ titration method (Jain et al., 2003). Reading was taken by every 7 days interval starting from the first day of transplanting and continued to sixteenth week of transplanting. Data are presented as line and bar graphs using MS Excel.

\section{Results and Discussion}

3.1. Carbon and nitrogen concentration in soils A general declining trend in carbon and nitrogen concentrations in soils was observed with the increment of soil depths, except for nitrate nitrogen (Figure 1). Carbon contents in the top soil are usually found to be the maximum because of application of organic residues in the surface soil. Moreover, there are regular falling and incorporation of crop leaves and other plant parts. The higher availability of organic matter in the top soils has profound influence on soil microbial population, which on the other hand, also contributed to increased carbon level in soils. Among three different manures and residues, poultry manure contributed to more carbon in soils followed by rice straw and cowdung (Figure 1a). In the top $5 \mathrm{~cm}$ soils, carbon contents were $1.25,0.90$ and $0.99 \%$ in the PM, CD and RS treatments, respectively, while in the $20-30 \mathrm{~cm}$ soil depths these values were $0.70,0.57$ and $0.58 \%$, respectively. The average carbon contents in $0-30 \mathrm{~cm}$ soil depths were $0.95,0.74$ and $0.79 \%$ in PM, CD and RS treatments, respectively. Poultry manure is more effective in building soil $\mathrm{C}$ than rice straw and cowdung, possibly due to the presence of more humified and recalcitrant $\mathrm{C}$ forms in poultry manure (Liu et al., 2013). Soil microbes broke down poultry manure where easily decomposed portions of organic material disappeared relatively quickly, while more resistant part known as humus leaving behind.

In addition to inherent soil nitrogen and inorganic fertilization, upon microbial decomposition of the organic matter it also releases nitrogen and other nutrients in the top soils. Therefore, nitrogen contents were also found the maximum in the top soils (Figure 1b). In the top $5 \mathrm{~cm}$ soils, total nitrogen contents were 
$0.122,0.100$ and $0.091 \%$ in the PM, CD and RS treatments, respectively, while the average values in $0-30 \mathrm{~cm}$ soil depths were $0.087,0.074$ and $0.071 \%$, respectively. Poultry manure was found more efficient to improve soil fertility as it contains more nutrients compared to cowdung and rice straw. As per fertility ranking, nitrogen
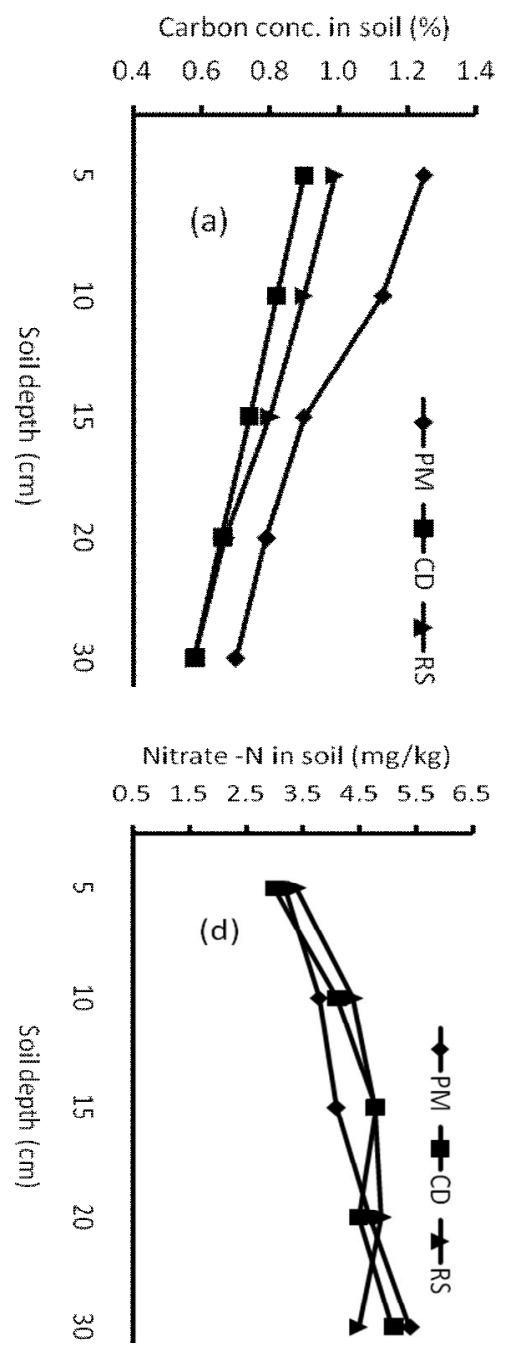

status in the top soils were low, while the average status in $0-30 \mathrm{~cm}$ soil depths were very low (BARC, 2005). Nitrogen added to the soil is subject to several changes (transformations) that ensure the availability of $\mathrm{N}$ to plants. The available forms of nitrogen in soils for plant uptake are ammonium $\left(\mathrm{NH}_{4}^{+}\right)$and nitrate $\left(\mathrm{NO}_{3}{ }^{-}\right)$.
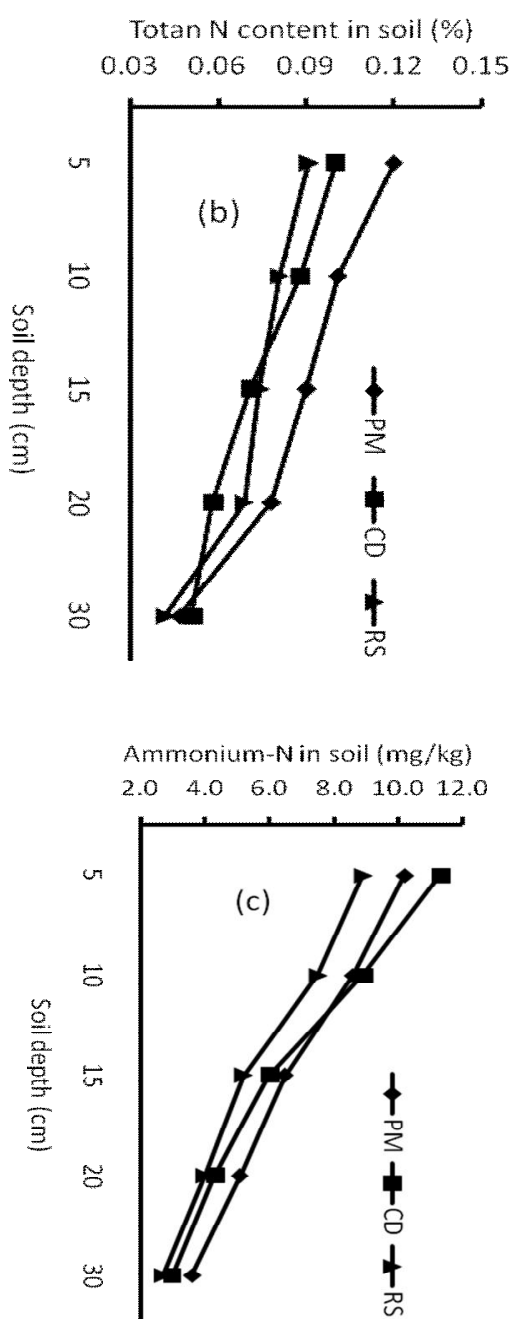

Figure 1. Carbon and nitrogen dynamics in soils under different management practices and soil depths 
These transformation and dynamics of nitrogen in soils depend on the aeration and submergence of soils. Bacteria decompose organic material and release ammonium $\left(\mathrm{NH}_{4}{ }^{+}\right)$nitrogen to soils, which is predominant in anaerobic condition. Ammonium nitrogen has properties that are of practical importance for nitrogen management in soils. The ammonium nitrogen contains positive charge $\left(\mathrm{NH}_{4}^{+}\right)$and therefore, is attracted to negatively charged soil and soil organic matter which protects its downward movement from soil systems. Therefore, ammonium nitrogen was found higher in the top soils compared to deeper soil layers in all three types of manure and residue application (Figure 1c).

The ammonium form of nitrogen is subject to other changes in the soil system through nitrification $\left(\mathrm{NO}_{3}^{-}-\mathrm{N}\right)$. Nitrification proceeds rapidly in warm, moist, well-aerated soils; however, it may also happen in the root rhizosphere where oxygen is present. Nitrate is a negatively charged ion and, therefore, like $\mathrm{NH}_{4}{ }^{+}$ it can't be attached to soil particles or soil organic matter. Nitrate nitrogen is water soluble and hence subject to rapid leaching below the crop rooting zone. Therefore, nitrate content in the top soils were found low, while it was higher in the lower soil depths under all treatments (Figure 1d). The average ammonium nitrogen in the top $5 \mathrm{~cm}$ soils was found about $10 \mathrm{mg} \mathrm{kg}^{-1}$, while in the $20-30 \mathrm{~cm}$ soil depth it was $3 \mathrm{mg} \mathrm{kg}$ ${ }^{1}$. On the other hand, nitrate nitrogen in the top 5 $\mathrm{cm}$ soils was found about $3.2 \mathrm{mg} \mathrm{kg}^{-1}$, while in the $20-30 \mathrm{~cm}$ soil depth it was $5 \mathrm{mg} \mathrm{kg}^{-1}$.

\subsection{Carbon stock, carbon sequestration and carbon dioxide emission in soil}

The initial carbon concentration in soils under the poultry manure treatment was higher compared to those under cowdung and rice straw treatment. Therefore, the initial stock was also higher in PM treatment, which was also attributed to final carbon stock (Figure 2). Similar trend was observed both in the top 0-5 and $0-30 \mathrm{~cm}$ soil depths. In the top $0-5 \mathrm{~cm}$ soil depth, carbon sequestration was lower in the RS treatment $\left(0.35 \mathrm{t} \mathrm{ha}^{-1}\right)$ compared to PM $(0.47 \mathrm{t}$ $\left.\mathrm{ha}^{-1}\right)$ and CD $\left(0.50 \mathrm{t} \mathrm{ha}^{-1}\right)$ treatments, while the difference in carbon sequestration between PM and $\mathrm{CD}$ treatments was found to be narrow (Figure 2a). In the top 0-30 cm soil depth, carbon sequestration was somewhat higher in the PM treatment followed by $\mathrm{CD}$ and RS treatments, where carbon sequestration in soils under PM treatment was $1.46 \mathrm{t} \mathrm{ha}^{-1}$, while it was 1.26 and $1.19 \mathrm{t} \mathrm{ha}^{-1}$ in CD and RS treatments, respectively (Figure 2b).

The weekly emission patterns of $\mathrm{CO}_{2}$ from soils under different treatments are presented in Figure 3. It was found that emission of $\mathrm{CO}_{2}$ started to increase gradually from the first week of rice transplanting and it reached the maximum in fourth to fifth weeks and after that a decreasing trend was observed and then again remained stable during thirteenth to sixteenth weeks irrespective of treatments and rice growing seasons. The emission of $\mathrm{CO}_{2}$ was comparatively higher in $\mathrm{T}$. aman season than in Boro season in all the treatments. In $\mathrm{T}$. aman season, rice was transplanted during the first week of August and the air temperature as well as soil temperature was high at that time, which favored rapid microbial decomposition of added organic manures and therefore, carbon dioxide emission was higher at that time. In $\mathrm{T}$. aman 2011, the highest emission of $\mathrm{CO}_{2}$ was recorded in the PM treatment in the $4^{\text {th }}$ week of transplanting, which was $870 \mathrm{~kg} \mathrm{CO} /$ ha/week (Figure 3a), while in Boro season the highest value (612 $\mathrm{kg} \mathrm{CO} / \mathrm{ha} /$ week) was found in the fifth week of transplanting under the same treatment (Figure 3b).

In the first week of T. aman 2011, the amounts of $\mathrm{CO}_{2}$ emissions were 450, 390 and 365 $\mathrm{kg} / \mathrm{ha} /$ week in PM, CD and RS treatments, respectively, while in the sixteenth week these values were reduced to 219, 250 and 298 $\mathrm{kg} / \mathrm{ha} /$ week, respectively (Figure 3a). It was noticed that at the beginning, emission of $\mathrm{CO}_{2}$ was the highest in PM treatments followed by $\mathrm{CD}$ and RS treatments, while at the end the maximum emission was recorded in the RS treatment followed by $\mathrm{CD}$ and PM treatments 
(Figure 3). During the sixteenth weeks of rice growing season, the recorded emissions of $\mathrm{CO}_{2}$ in T. aman 2011 were 7709,7513 and 7957 $\mathrm{kg} / \mathrm{ha}$, in PM, CD and RS treatments, respectively. In Boro 2012 the equivalent values were 6420,5990 and $6747 \mathrm{~kg} / \mathrm{ha}$, respectively, which indicated that rice straw released more $\mathrm{CO}_{2}$ compared to poultry manure and cowdung.

It was reported that manure is more resistant to microbial decomposition than plant residues. Consequently, for the same carbon input, carbon storage is higher with manure application than with plant residues (Feng and Li, 2002). Among the organic materials treatments, the lowest organic carbon in soils was found in RS which attributed to the highest emission of $\mathrm{CO}_{2}$ in this treatment. This may be due to the use of higher rates of $\mathrm{N}$ fertilizer in $\mathrm{RS}$ treatment compared to $\mathrm{PM}$ and $\mathrm{CD}$, which may stimulate soil microbial activity and eventually increase the $\mathrm{CO}_{2}$ emission. Therefore, treatments with inorganic nitrogen fertilizers favor degradation of organic matter, which ultimately result in low carbon content in soils. This is in agreement with the Halvorson et al. (2002). The rates of carbon sequestration in soils under different management practices in the present study were found low.
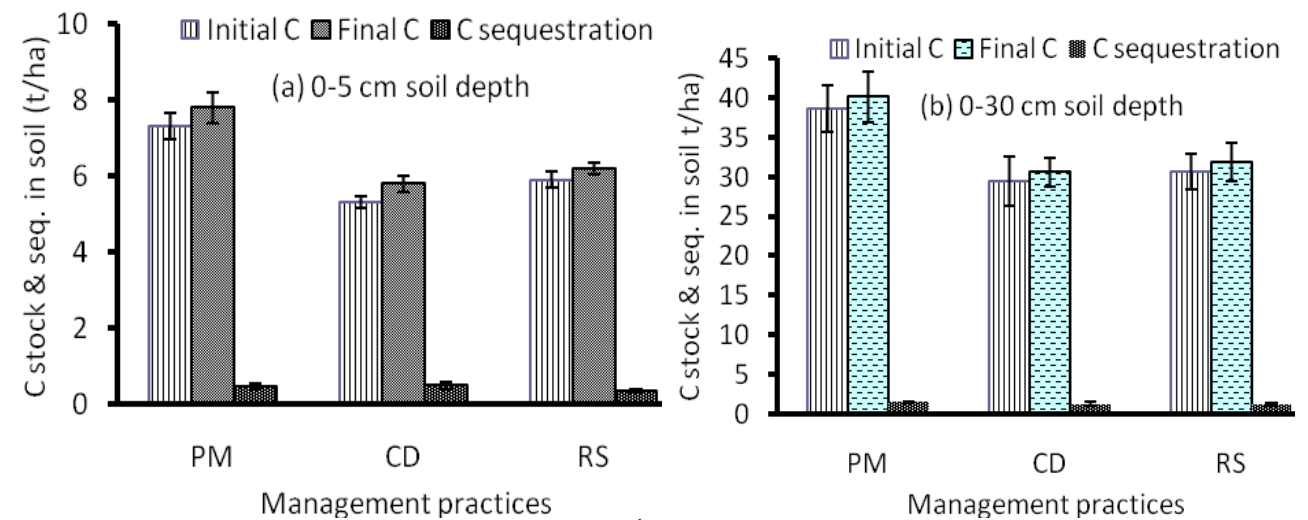

Figure 2. Carbon stock and sequestration $\left(\mathrm{t} \mathrm{ha}^{-1}\right)$ in soils under different management practices after two crop seasons $($ Seq. $=$ sequestration)

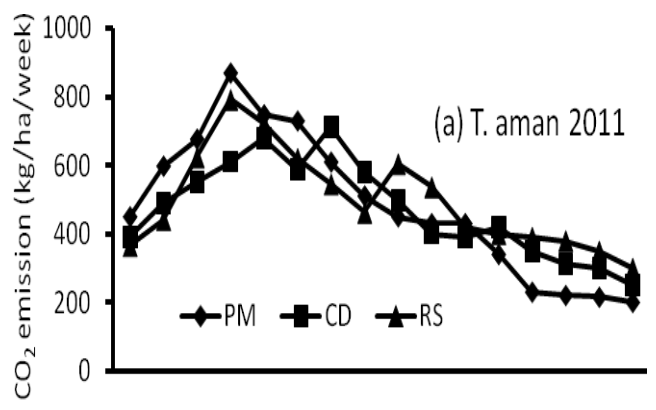

1234556789910111213141516

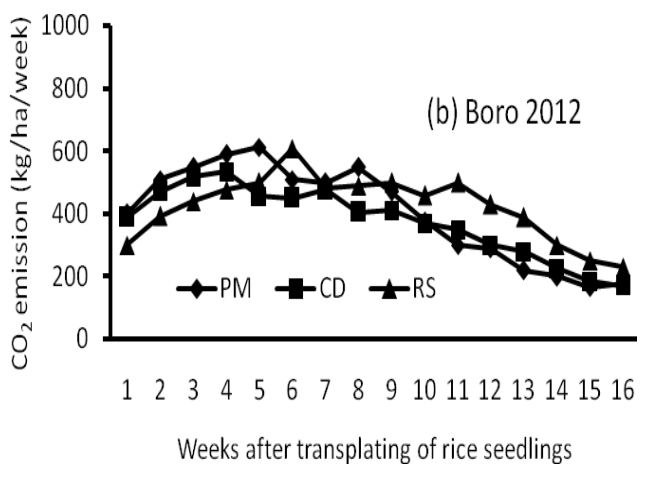

Weeks after transplating of rice seedlings

Figure 3. Carbon dioxide emission $\left(\mathrm{kg} \mathrm{CO}_{2} / \mathrm{ha} /\right.$ week) from soils under different management practices in T. aman and Boro seasons 
However, it indicates a positive sign of carbon accumulation, where it is really a challenge to increase and maintain carbon level in soils under prevailing hot and humid climatic conditions favorable to rapid microbial decomposition of organic matter. This small increment in soil carbon may reduce the atmospheric $\mathrm{CO}_{2}$. It is reported that approximately $12 \%$ of the soil $\mathrm{C}$ stock is present in cultivated soil and about $35 \%$ of the global land surface is occupied by agricultural soils, and hence proper soil management can potentially be a powerful tool for climate change mitigation through $\mathrm{C}$ sequestration (Betts et al., 2007; Lal et al., 2011).

\section{Conclusions}

Carbon and nitrogen dynamics in soils are complex phenomenon, which vary depending on soil and crop management practices and may have profound effects on global warming and climate change. Poultry manure was found efficient to increase carbon and nitrogen in soils compared to rice straw and cowdung, which decreased with increased soil depths irrespective of residues. Positive trend of carbon enrichment in soils was found while poultry manure, cowdung and rice straw were applied, which could be monitored and maintained through regular replenishment of organic materials in soils. During the sixteenth weeks of rice growing season cumulative carbon dioxide emission was higher in the rice straw treatment compared to poultry manure and cowdung. Any type of soil and crop management practices that could enhance carbon contents in soils should be considered and recommended for farmers' practice. Use of crop residues, animal manures, biochar, minimum or zero tillage, crop rotation, balanced fertilization and many other available organic sources may replenish and increase carbon stock in soils and bring multitude of benefits for agricultural sustainability.

\section{Acknowledgements}

The research was conducted under the National Agricultural Technology Program (NATP), Phase 1of Bangladesh Agricultural Research Council (BARC) funded by World Bank, IFAD \& Government of Bangladesh.

\section{References}

BARC (Bangladesh Agricultural Research Council). 2005. Fertilizer Recommendation Guide. Bangladesh Agricultural Research Council (BARC). Soil Publication No. 45. Farm Gate, Dhaka 1215, Bangladesh, $260 \mathrm{p}$.

Benbi, D. K. and Senapati, N. 2010. Soil aggregation and carbon and nitrogen stabilization in relation to residues and manure application in rice-wheat systems in northwest India. Nutrient Cycling in Agroecosystems, 87:233-247.

Betts, R. A., Falloon, P. D., Goldewijk, K. K. and Ramankutty, N. 2007. Biogeophysical effects of land use on climate: model simulations of radiative forcing and largescale temperature change. Agriculture Forestry and Meteorology, 142:216-233.

Bhatia, A., Aggarwal, P. K., Jain, N. and Pathak, H. 2011. Greenhouse gas emission from rice-wheat growing areas in India: spatial analysisand upscaling. Greenhouse Gas Science and Technology, 2: 115-125.

Feng, Y. and X. Li. 2002. A tool to determine long-term sustainable manure application rate for Alberta soils. Report to CanadianAlberta beef industry development fund, $120 \mathrm{p}$.

Halvorson, A. D., Wienhold, B. J. and Black, A.L. 2002. Tillage, nitrogen and cropping system effects on soil carbon 
sequestration. Soil Science Society of America Journal, 66:906-912.

Jain, M. C., Pathak, H. and Bhatia, A. 2003. Measurement of greenhouse emission from soil and developing emission inventories. In: Soil and greenhouse effect monitoring and evaluation. H. Pathak and S. Kumer (eds.), CBS Publishers and Distributors, New Delhi, India, 65-78 pp.

Karim, Z. and Iqbal, A. 2001. Impact of Land Degradation in Bangladesh. Bangladesh Agricultural Research Council. Farm Gate. Dhaka, 60-160 pp.

Karim, Z., Ibrahim, A., Iqbal, A. and Ahmad, M. 1990. Droughts in Bangladesh Agriculture and irrigation schedules for major crops, Bangladesh Agriculture Research Council, Dhaka.

Lal, R., Delgado, J. A., Groffman, P. M., Millar, N., Dell, C. and Rotz, A. 2011. Management to mitigate and adapt to climate change. Journal of Soil and Water Conservation, 66:276-285.

Liu, E., Yan, C., Mei, X., Zhang, Y. and Fan, T. 2013. Long-term effect of manure and fertilizer on soil organic carbon pools in dryland farming in northwest China. PLoS One, 8(2): e56536.

doi:10.1371/journal.pone.0056536.
Manzoni, S., Jackson, R. B., Trofymow, J. A. and Porporato, A. 2008. The global stoichiometry of litter nitrogen mineralization. Science, 321: 684-686.

Marland, G., Garten, C. T. Jr., Post, W. M. and West, T. O. 2004. Studies on enhancing carbon sequestration in soils. Energy, 29:1643-1650.

Page, A. L., Miller, R. H. and Keeney, D. R. 1982. Methods of Soil Analysis. 2nd Edn., Amercen Society of Agronomy, Madison, WI., USA.

Rahman, M. M. 2010. Carbon sequestration options in soils under different crops and their management practices. The Agriculturists, 8(1): 90-101.

Rahman, M. M. 2013. Nutrient use and carbon sequestration efficiencies in soils from different organic wastes in rice and tomato cultivation. Communications in Soil Science and Plant Analysis, 44(09): 1457-1471.

Soderstorm, B. O., Hedlund, K., Jackson, L. E., Kattere, T., Lugato, E., Thomsen, I. K. and Jorgensen, H.B. 2014. What are the effects of agricultural management on soil organic carbon (SOC) stock? Environmental Evidence, 3:1-8. 